\title{
Flexibility of Scope, Type and Temporality in Mustang, Nepal. Opportunities for Adaptation in a Farming System Facing Climatic and Market Uncertainty
}

\author{
Nina Holmelin ${ }^{1, *}$ and Tor Halfdan Aase ${ }^{1,2}$ \\ 1 CICERO Center for International Climate and Environmental Research-Oslo, \\ P.O.Box 1129 Blindern, N-0318 Oslo, Norway \\ 2 Department of Geography, University of Bergen, 5020 Bergen, Norway; \\ E-Mail: Tor.Aase@geog.uib.no
}

* Author to whom correspondence should be addressed; E-Mail: nina.holmelin@cicero.oslo.no; Tel.: +47-22-85-85-72; Fax: +47-22-85-87-51.

Received: 12 December 2012; in revised form: 23 January 2013 / Accepted: 1 March 2013 / Published: 25 March 2013

\begin{abstract}
Climate change is projected to increase the seasonality in river flows in the great river systems of Himalaya and impose challenges to regional food production. Since climate change increases the uncertainty in local weather patterns, people's ability to maintain local agricultural production will probably depend on how flexible the local farming systems are to adjust to unpredictable changes. The objective of this paper is to investigate the flexibility of one such farming system which is located in Mustang, Nepal, Himalaya. Defining flexibility as "uncommitted potentialities for change" following Gregory Bateson, the paper identifies opportunities for change in the farming system, as well as factors that constrain flexibility. Further developing the concept of flexibility, it is suggested that flexibility may be analyzed in terms of scope, type and temporal flexibility. Although there are several underexploited resources in the studied farming system, the present situation is not regarded as one of irrational and suboptimal exploitation of resources. Instead, unexploited resources imply opportunities for change, which provide the system with flexibility to rapidly adjust agricultural production to varying and uncertain conditions of production.
\end{abstract}

Keywords: flexibility; farming systems; climate change; adaptive capacity; uncertainty; Mustang; Nepal; Himalaya 


\section{Introduction}

A book recently published by the United Nations University bearing the title "Weathering Uncertainty", highlights how rural communities have elaborated numerous strategies to adapt to unstable environments, such as diversifying their use of the landscape and maintaining genetic and species diversity in fields and herds [1]. While modern agriculture tends to be highly standardized, specialized and intensified, small-scale farmers have often been viewed as traditional, irrational, and resistant to change [2]. However, several studies of mountain farming communities have shown that the diversified practices which often characterizes small-scale farming systems enable people to be flexible in response to changes [3-6]. In this paper we argue that small-scale farming systems may indeed be highly flexible, although there are also constraints to flexibility. To analyze farming system flexibility is one way of studying adaptive capacity in small-scale farming systems under uncertain conditions of production, which has implications for the general sustainability of local food production systems.

The impacts of climate change on the Himalayan region are likely to include raising average temperatures and increased melting of ice and snow during this century [7], particularly in mountain areas up to 6,000 meters above sea level [8]. As a consequence, the peaks in meltwater runoff are expected to shift to winter and early spring, away from summer and autumn when the demand is greatest [9]. Mountainous regions of Nepal have been observed to amplify the regional warming trend and show high sensitivity to climate change [10]. Temperatures in alpine areas are predicted to increase by disproportionate rates and as much as $5-6{ }^{\circ} \mathrm{C}$ during the 21 st century [11], depending on near-future achievements in reducing global emissions of greenhouse gases and on the sensitivity of the climate system.

The outlooks for precipitation patterns are however more complex and uncertain [9]. Shifts in the monsoon patterns have been observed in Himalaya over the last few decades, but the picture remains ambiguous [10,12]. Climate projections show that increased variability in precipitation is expected in the years to come $[7,8]$. At the local scale however, the vast differences in micro-climatic conditions that characterizes complex mountain environments such as Himalaya [13] make climate prospects for specific localities highly uncertain [6]. As climate change add to the natural variability inherent in the climate system, the prospects for future climatic conditions for Himalayan farmers become increasingly difficult to predict [14]. For mountain farmers who depend on the weather for securing good harvests, changing local temperatures and water availability have significant impacts on their ability to maintain local food production. While the sharp rise and instability in global food market prices the recent years have multiple causes both at the supply and demand side [15], food prices are expected to remain high and volatile in the years to come [16]. The combination of climatic and market uncertainty that faces Himalayan small-scale farmers raises the question of how the farmers may adapt their food production systems to this uncertainty. While a common response to risk is to build resilience, uncertainty is perhaps better met with flexibility. Flexibility generally refers to the adaptive capacity of a system in a situation of uncertainty [17].

This paper investigates the flexibility of one such farming system which is located in Lower Mustang, Nepal Himalaya. The paper firstly explores theoretically the concept of flexibility and suggests that flexibility may be analyzed in terms of three specific aspects: Flexibility of scope, 
flexibility of type and temporal flexibility. Defining flexibility as "uncommitted potentialities for change" ([18], p. 497) the paper next identifies opportunities for change in the studied farming system, as well as factors that constrain system flexibility. Lastly, a discussion on the transferability of conclusions is included.

\section{Farming System Flexibility}

Empirical studies have shown that through flexible diversification of crops and productive strategies and the ability to rapidly adjust agricultural production to dynamic environments, small family farms have indeed proved to be highly successful $[17,19,20]$, despite the dominant farming policy to "get big or get out" ([19], p.391). Most of these studies focus on flexible decision making at the household farm level [17,19,21]. One exception is Aase et al. [6], who analyze farming system flexibility at community level as the range of opportunities for change that exist in a mountain farming system, which are currently uncommitted but can be explored if necessary. Aase et al. [6] draws on Gregory Bateson's [18] general notion of flexibility in complex systems.

Bateson defines flexibility as "uncommitted potentialities for change" ([18]. p. 497). He describes a system as consisting of a set of interlinked variables where each variable has an upper and a lower threshold of tolerance. Within its thresholds the variable's value can be moved to reach adaptation, but when a variable is exposed to stress and takes on a value close to one of its thresholds, the system lacks flexibility. If Bateson's terminology is transferred to farming systems, the system variables refer to the factors of production in the farming system, such as labor, cultivated land, water, pastures, forests, livestock and capital. Since sufficient capacity in all the factors of production must be available in order to enable cultivation, relative shortage of any crucial factor of production imposes a constraint to production in the farming system. Social organization and cooperation at the local level, including formal and informal rules for entitlement to resources, influence how the system is managed. Farmers are the managers of the farming system and can make decisions that influence farming system flexibility, although factors outside the control of the farmer, for instance climatic variability, also affect the performance of the farming system.

When one of the system variables is stressed so that its used capacity is near the upper or the lower tolerance limit, Bateson holds that the interlinked nature of the system leads to spreading of inflexibility because other variables cannot be adjusted without pushing the stressed variable beyond its threshold. The solution is then to rebuild a positive budget of flexibility, by saving up a buffer zone of unexploited capacity that can "be spent (like fat) upon needed change" ([18], p. 497). It follows that the only way to preserve system flexibility is to avoid permanent exploitation of the maximal capacity in system variables. Flexibility then becomes the exact opposite of intensification, in other words to avoid pushing the value of a variable to its threshold. The general flexibility of a system depends on keeping many of its variables at values somewhere in the middle of their space of tolerance, to make sure that there is unexploited capacity free to be used in times of need.

For the purpose of analyzing flexibility in small-scale farming systems, we distinguish between three aspects of flexibility (Figure 1). First, flexibility of scope refers to the buffers of unexploited capacity in the system variables, which is the main concern of Bateson. Available, but currently unused capacity in the factors of production such as land, manure, water, labor and capital provide the 
farming system with uncommitted potentialities for change through the opportunity to employ these productive resources if the farmers choose to do so. However, to only increase the scope of production through intensification reduces flexibility in the long run. Therefore, the second aspect is flexibility of type, which refers to the uncommitted potentialities for change in the composition of crops, species and productive practices in the farming system. Diversification increases flexibility of type by expanding the opportunity situation of farmers, that is, by increasing the range of possible crops to cultivate, the number of wild plants and forest resources to collect and ways of shifting productive capacity from one good to another. Flexibility of type thus resembles what Weiss [20] and, by implication, Carlsson [22] calls operational flexibility. The third aspect is temporal flexibility, which may be analyzed in both short-term and long-term perspectives [22,23]. Short-term temporal flexibility here refers to the ability to rapidly alternate between different crops and productive practices and reallocate available capacity of production factors to where it is most needed. Long-term temporal flexibility has parallels to Carlsson's term strategic flexibility, which he refers to as the strategic positioning of a firm with respect to a menu of choices for the future. Transferred to farming systems, long-term temporal flexibility is a matter of farmer's decisions regarding how they plan for the future under conditions of uncertainty. For instance, to maintain a certain level of local food production, even if non-agricultural work for the time being seems more profitable, is a strategic decision which provides the farming households with temporal flexibility to increase or reduce, diversify and change agricultural production also in a long-term perspective. If agriculture is fully abandoned for many years, then fields will not be maintained, livestock cannot be kept and practical competence may be lost. As time goes by, the investment costs of returning to an abandoned farm increases, although leaving the land fallow could have some positive effect on soil fertility. The system in such a situation has crossed its lower thresholds of tolerance and consequentially lost much of its flexibility. Flexibility must therefore be used once in a while in order to prevail [18].

Figure 1. Three aspects of flexibility in a small-scale farming system.

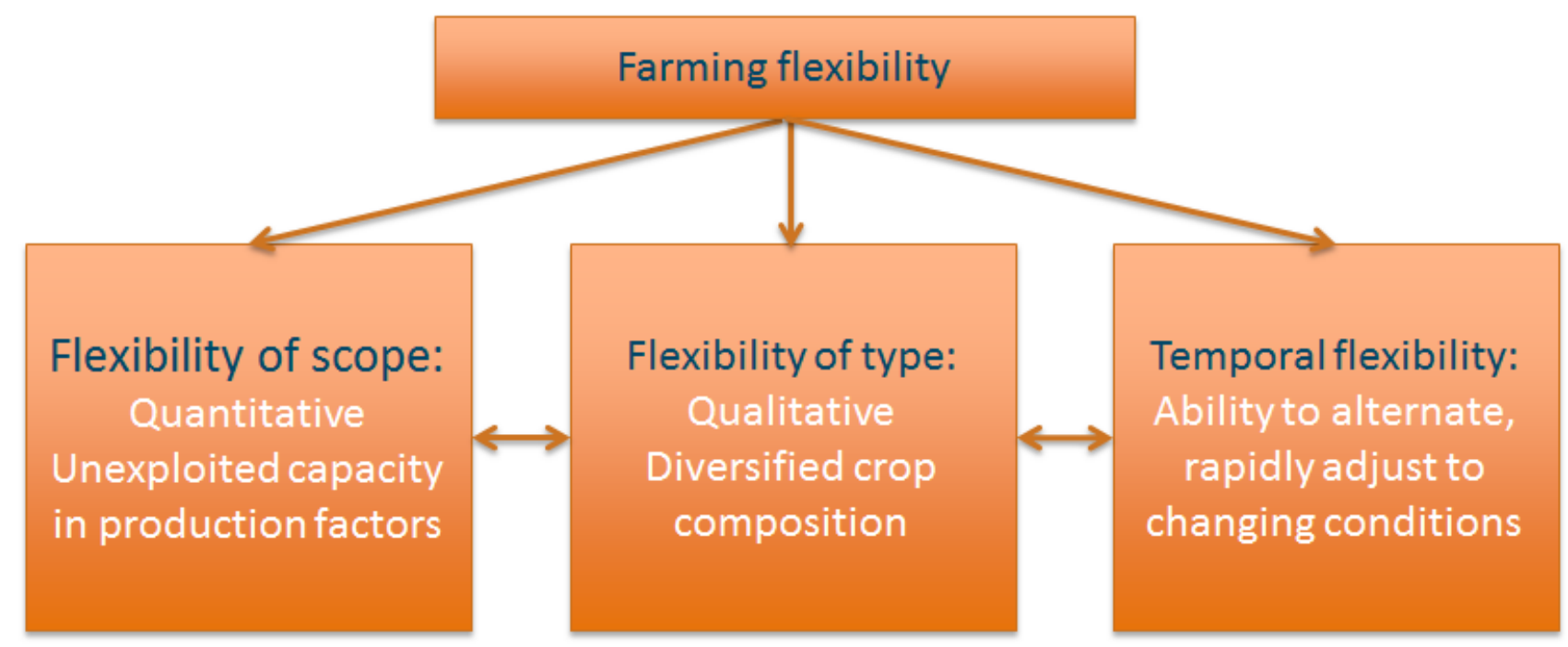




\section{Analytical Approach}

This paper analyses the flexibility of one particular small-scale Himalayan farming system by means of the terms flexibility of scope, flexibility of type, and temporal flexibility. By looking for the potentials for change in the farming system as well as factors that constrain the performance of the system, flexibility is seen as an expression of the capacity of this farming system to adapt under conditions of climatic and market uncertainty.

Social inequality exists even in small and tightly interconnected rural communities, and households may have differentiated capabilities to realize existing opportunities for change. Principles of social differentiation such as caste, religion, income, age and gender may affect households' capability to change. Households are important organizational units and the basic economic unit in terms of land and agricultural production. However, in this case from Lower Mustang, Nepal, the households' participation and membership in the village community council is decisive for their entitlement to common property resources such as irrigation water, pastures and forests. The endowments of such common property resources belong to the community. All households are represented in the council and the council leader (gemba) is appointed on annual rotation among all present males between the age of 18 and 60 . The council ensures equitable distribution of rights and responsibilities; it settles disputes and calls all households for community work whenever this is needed. The same system of local governance is found in other Trans-Himalayan farming communities too [5]. While each household makes decisions for its private farm system [24], the village council manages the community farming system of Jharkot. A farming system is here defined as "any level of unit(s) engaged in agricultural production as it is wedded in a social, political, economic, and environmental context" ([25], p. 13). In this case the village level of scale is in focus since access to and management of pastures, forests, irrigation water and herding responsibilities are organized by the community. Inequality between and within households is not a subject for analysis in this paper, as the objective here is rather to explore the opportunity situation at the community level, which reflects the general flexibility of the farming system.

\section{The Farming System of Jharkot}

Jharkot is one of four villages in Muktinath Village Development Committee (VDC) of Mustang District, Western Nepal (Figure 2), and is located at 3550 meters above sea level. The Muktinath valley surrounding Jharkot lies at $83^{\circ} 35^{\prime}$ east, $28^{\circ} 49^{\prime}$ north. The people of Jharkot are culturally and linguistically Tibetan (Bhotias), though they are residents of Nepal. They confess to Buddhism and belong to the ethnic groups Gurung and Thakuri. Until recently, no passable road for cars reached Jharkot, meaning that all goods had to be carried for six days by porters or pack animals to reach the markets. In 2006 Jharkot was connected by road to the district center Jomsom, while a full road connection to the city Pokhara was completed in 2008. Once motorized transport was made possible, the transport cost for goods was reduced by $75 \%$ and the transport time declined from six days by pack animals to one or two days by car. The local price of rice imported from lower parts of Nepal declined by $32 \%$ with the completion of the road. 
Figure 2. Map of Jharkot village in Muktinath VDC, Lower Mustang, Nepal.

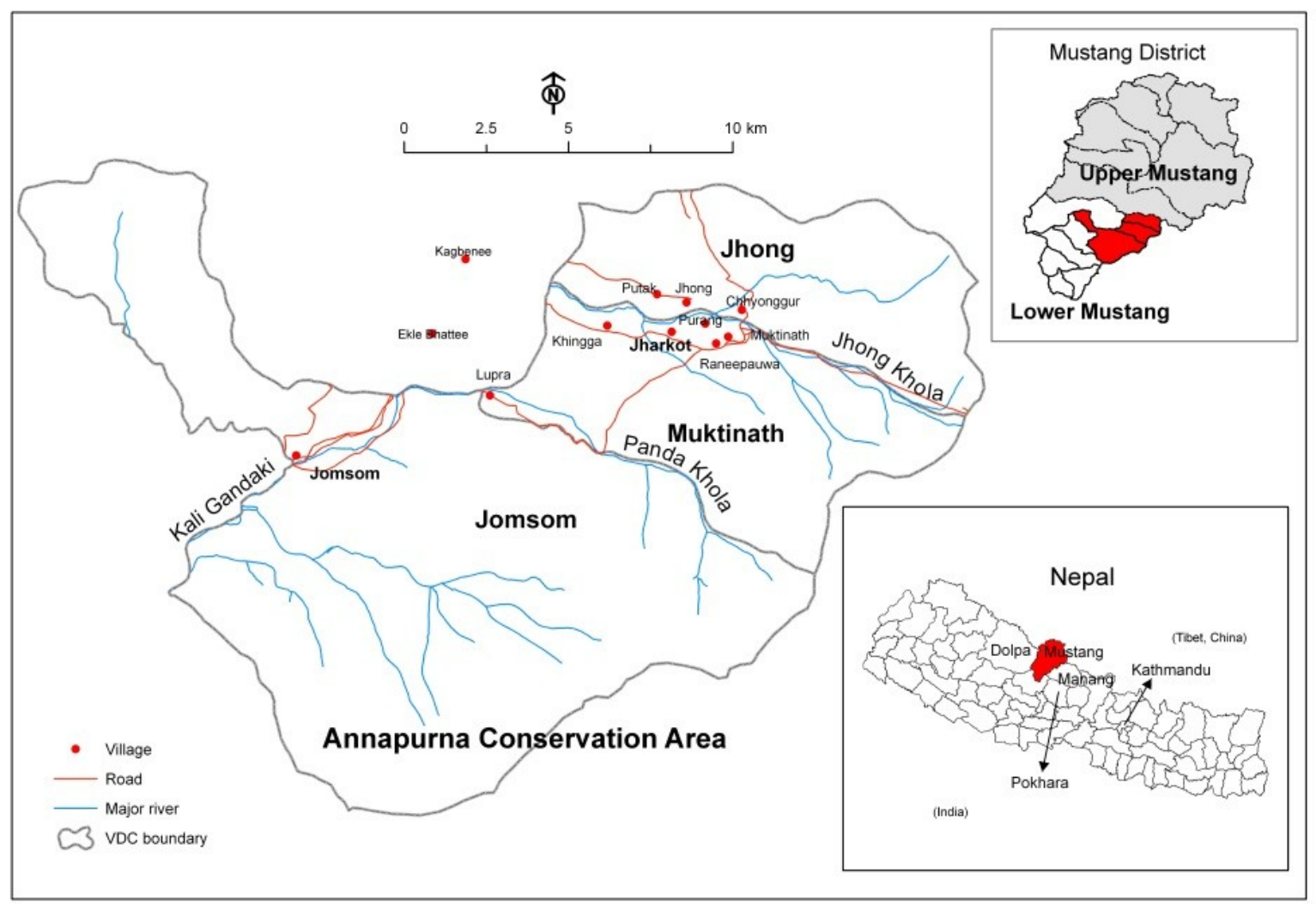

People in this area practice a traditional form of agro-pastoralism which is quite common in mountain regions of Nepal. Barley (Hordeum vulgare), wheat (Triticum aestivum) and buckwheat (Fagopyrum esculentum, F. tataricum) are cultivated in terraced fields, while fruits and vegetables are cultivated in orchards. Yak-cow hybrids (jhopa, or $d z o$ ) serve as draft animals while horses are kept mainly for travel. Herds of cows, goats and sheep are brought out daily to graze in the alpine meadows, while they are stall-fed during the winter with foliage, grass and crop residues. The winter fodder is cut during the growing season and stored for the winter. The livestock provide manure which is essential for maintenance of soil fertility through the recycling of micronutrients from forests and pastures to the cultivated fields. Manure is thus an important link in the agro-pastoral farming system. No inorganic fertilizers or pesticides are currently used in Jharkot. All households in the village have entitlements to the pasture areas that exclusively belong to the community. All Jharkot households also have entitlements to collect wood from a nearby community forest, although foliage and wood from privately planted trees are more commonly used. Figure 3 represents a model of the farming system.

Streams of meltwater run down from the snow and ice covered mountain peaks surrounding the valley. Located in the rain shadow of the great Annapurna mountain range, the valley is semi-arid and cultivation is fully dependent on irrigation. A climate characterized by strong winds and intense sunlight causes high evaporation and contribute to the semi-arid conditions [26]. Exact and recent figures of precipitation are scarce, but Fort [27] reports that annual precipitation is approximately $352 \mathrm{~mm}$ (ten year average). However, even between villages located a few kilometers apart, there are large variations in precipitation due to the steep topography of the area. In Jharkot, most of the precipitation falls in July and August while only little falls as snow during the winter months, which 
probably indicates the influence of the monsoon and contrasts the climate of Muktinath Valley from that of the Western Himalaya [27].

Seasonal water scarcity and a short growing season impose climatic constraints to agricultural production in Jharkot. Yields are thus generally lower in Jharkot than in farming systems located at lower altitudes. Local agricultural production can support the population for approximately six months of the year [28]. Seasonal migration during the cold and lean winter has for centuries been a common adaptive strategy. Historically, the people of Mustang took part in the Trans-Himalayan trade between Tibet and India, bringing salt and wool from Tibet down to the lowlands and returning with food grains. Large herds of goats, sheep and mules were used as pack animals [29] along the Kali Gandaki river bed, one of the main trading routes between Tibet and the lowland markets [30]. The trade flourished from the 15th century and especially throughout the 19th century [31] before it declined with the Chinese occupation of Tibet in 1959.

Today, alternative livelihoods in tourism, transport services and labor migration accompany agricultural production. Widespread abandonment of agricultural land has occurred both in Jharkot and more generally in Mustang over the last couple of decades [26], just as in the neighbor district Manang [6,32]. The herds of animals and the number of people in Jharkot have historically been higher than today. While there were 75 households in Jharkot twenty years ago, today there are 62 . The number of large households in the village has also declined. Similarly, while 216 households were registered in Muktinath VDC in 2001 [26], now there are 169. Still, agro-pastoralism constitutes the economic and social backbone of Jharkot community. The terraced fields which are now abandoned could in fact contribute to flexibility in the farming system, as agricultural production may be increased if people in the future choose to return to farming [6].

Figure 3. The farming system of Jharkot.

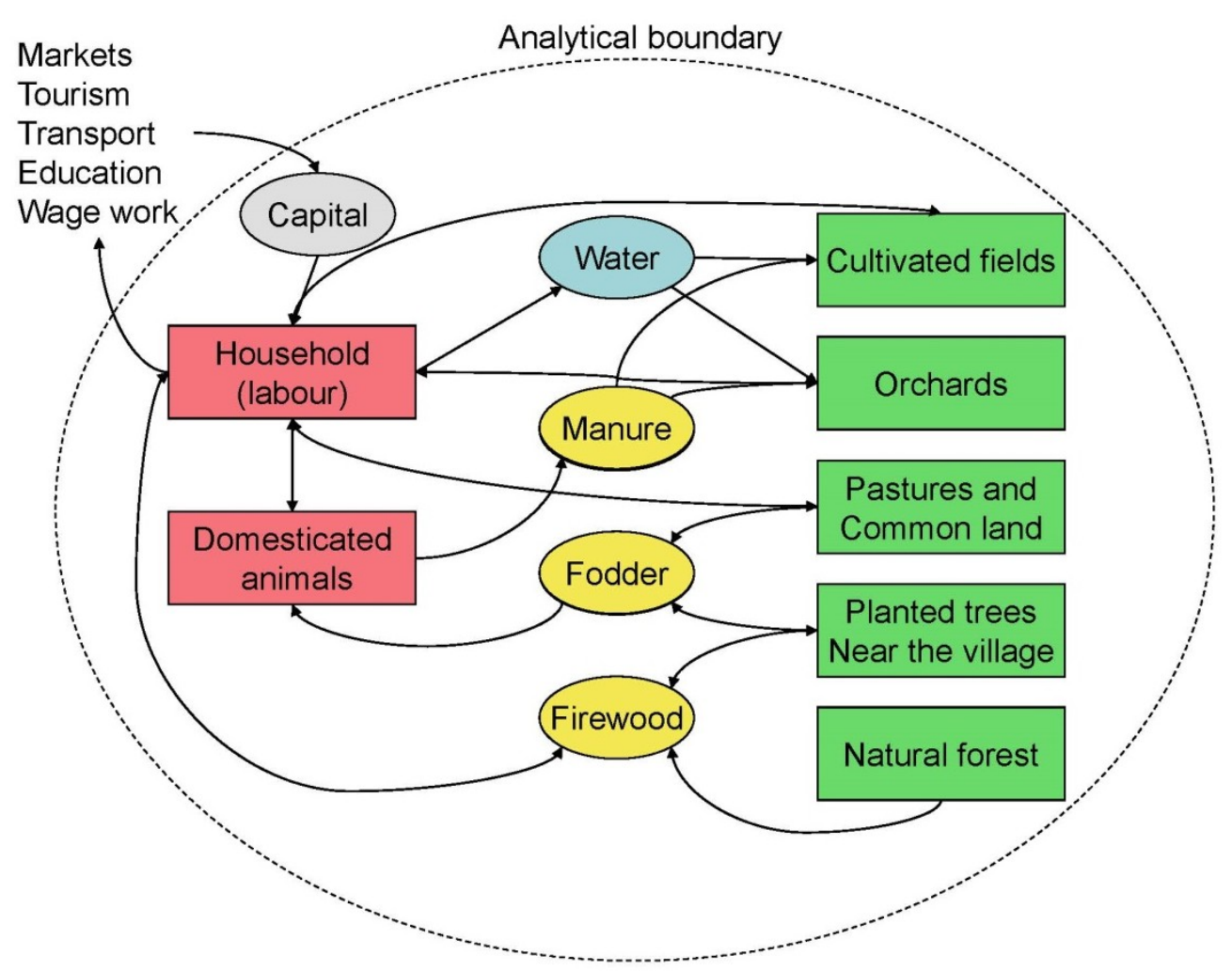




\section{Flexibility of Scope}

Due to the high-mountain environment with a naturally short growing season, subsistence production in Jharkot has traditionally been supplemented with trade and food import. Engagement in alternative livelihoods to farming has contributed to net out-migration and the abandonment of agricultural land [26]. The current scope of agricultural production should therefore not be confused with the maximal potentials for production in the farming system, as the capacity of many farming system variables are far from fully exploited in Jharkot. The scope of food production has historically been higher through cultivation of a greater number of terraced fields, combined with larger herds of cows, goats, sheep, and yaks. The yaks range in herds far from the villages in pastures located higher than 4,000 meters above sea level and do not provide suitable manure for fertilization of fields, but are kept by Tibetan communities for milk, meat and wool. Today, many households have chosen to reduce their herds of livestock, and only a few wealthier households hold yaks.

The pastures have historically proven able to support much larger numbers of animals, also during the winter when animals must be stall-fed. There is thus flexibility of scope in winter fodder availability, unexploited capacity which gives the opportunity to increase the utilization of fodder resources. Firstly, more cultivation produces more weed and crop residuals, and consequently more fodder. Secondly, more trees could be planted in village lands which would provide foliage for fodder and bedding, although newly planted trees would need about three years of growing before they yield. A third opportunity for increasing fodder availability is to alter the composition of the herds. The significant number of horses in the farming system already consumes large amounts of both grains and winter fodder without producing suitable manure for the fields [33]. In the neighbor district Manang, horses consume the produce of $16 \%$ of all cultivated land in the valley [6]. With the introduction of jeeps and motorbikes in Jharkot after the completion of the road, the importance of horses for travel is reduced. Thus, if winter fodder availability at times should be scarce, an uncommitted potentiality for change is to reduce the number of horses in the farming system and allow human consumption of the grains that are now spent as horse feed [6]. Larger herds of goats could potentially be raised instead. The reallocation of winter fodder from horses to goats would increase the returns of manure relative to winter fodder and relieve manure as a potential constraint for increased grain production. If farmers choose to reclaim abandoned fields and dedicate them not primarily to grain production but rather to vegetable cultivation, the number of poultry could be increased at the expense of horses, since poultry gives manure of high quality, but in much small amounts than goats and cows.

Horses have historically had a high cultural significance in Jharkot. Every year in August a horse race festival (Yartung) is held, an old tradition in the area. This is a still a popular event in the community and many young male migrants return to the village for the festival in time before the harvest. In Manang, horse keeping is an index of success [34] and traditionally they have the same high position in Mustang [29] as items of conspicuous consumption [35]. However, motorbikes have become increasingly popular in the valley the recent years, especially among young men. A motorbike indicates that the owner has been able to raise a significant amount of money and it gives income opportunities by driving Indian pilgrims to the nearby Muktinath temple complex. If motorbikes are currently substituting horses as items of conspicuous consumption, people might choose to increase the 
number of goats or cows at the expense of the number of horses. A shift to fewer horses would thus increase the production potential of the system.

The number of abandoned fields, underutilised pastures, planted trees and forests in Jharkot serve the farming system with flexibility through the uncommitted potentiality to reclaim land and increase manure producing livestock herds. Should the people of Jharkot find it necessary or beneficial to again increase their reliance on local food production, they can do so by allocating more of their labor into agriculture at the expense of alternative livelihoods. Additional labor needs can be met by hiring casual workers in peak periods and by encouraging more sharecropping, opportunities which have already been partly committed in Jharkot. Groups of casual workers from poorer neighbor districts to Mustang reside periodically in Jharkot, where they seek temporary work. Traditionally, casual workers were paid in kind; earning food and accommodation as the only payment for their labor, but now casual workers do earn some money in addition to food and shelter. Other migrants rent land by sharecropping. Usually, sharecroppers keep 50\% of the yields while the land owner gets the other half, but there are cases where sharecroppers are permitted to keep more than half of the yields. Instead of regarding the situation of declined agricultural production as one of suboptimal exploitation of resources, an alternative approach is to acknowledge that unexploited capacity involves opportunities for change which provide the system with flexibility to increase agricultural production in response to large-scale changes, such as rising food prices or reduced opportunities for off-farm income and labor migration.

However, one bottleneck in this farming system is the availability of irrigation water in the spring. Meltwater from snow and ice is essential for irrigation of barley and wheat crops from March to early June, before the monsoon rain reaches Jharkot. Water storage systems are constructed only for drinking water in a closed pipe system and for open animal ponds, but not for the significantly larger amounts of irrigation water. Irrigation rights rotate among the households in the village to ensure that all households have the chance to irrigate their fields at least twice during the dry spring period. Too little water may destroy significant shares of the major food crops. The short growing season restricts the time period for grain cultivation, allowing time for a second crop of the fast-growing buckwheat only after barley, which ripens earlier than wheat. If winter temperatures should rise in the future in the mountains surrounding Jharkot, more of the winter precipitation could fall as rain instead of snow, and thus run past the farming system at a time of year when the farmers cannot utilize the water for farming. However, if the growing season is prolonged with higher temperatures, there could be time for two crops per year even in the wheat fields, though only if sufficient amounts of irrigation water are available at the time of year when farmers need it. The future climate to which the farmers of Jharkot must adapt their farming system is in other words uncertain. People's adaptive capacity depends on how they deal with and respond to uncertain conditions of production.

\section{Flexibility of Type}

Over the years the people of Jharkot have experienced that they reduce the risk of crop failure if they rely on a wide diversity of crops and productive strategies, much similar to the experiences of small-scale farmers in other mountain regions [2,5]. Grain cultivation is complemented by vegetable and fruit production and collection of a wide variety of medicinal plants, herbs, fungi and berries from 
common lands. With the reduced transport costs to the market, people in Jharkot have started to explore new opportunities for market production. Some have constructed simple technology greenhouses for vegetable production. Apples are seen as a promising cash crop and many farming households in Jharkot have recently planted apple trees in one or two of their fields. Villages further south in Mustang district have for long been well known for their successful apple production, and now farmers in Jharkot see the potential to draw on the good reputation of "Mustang apples". To expand the scope of apple production from a few garden trees for subsistence to larger quantities of apples as a cash crop is to make use of the flexibility of type in the farming system, by shifting part of the production capacity of land, labor and water over from barley and wheat to apples. Although the shift demands investments for a few years before revenues can be obtained, the benefits of this shift are several: Once the apple trees are well established, they demand less labor than grain cultivation, cash crops are seen as a more attractive option than subsistence production for young people, the expectations for profit from market sale are high, and damaged apples not suitable for sale can still serve the purpose as animal feed. However, investments in commercial apple production also involve uncertainty, mainly in three ways. Firstly, fluctuating sales prices make commercial apple production occasionally unprofitable, despite the recent reduction in transportation costs. Competition from cheap Chinese apples could challenge Mustang apple producers. Mustang apples cost 130-140 NPR per kg in the urban markets, while imported Chinese apples in 2012 sold for 100-140 NPR per kilo in Kathmandu. Branding their apples as organic could however help to justify higher sales prices. Organic Mustang apples are in 2012 advertised for as much as 250 NPR per kilo delivered in Kathmandu. The second uncertainty is pest attacks which may destroy large shares of the harvest. Farmers reported of pest attacks deteriorating the apple quality in 2010. The third uncertainty is the risk of road blocks which inhibit the apples from reaching the market in a fresh state. Some farmers have however explored opportunities for making apple brandy, juice and dried apple rings, which are storable and thus less dependent on continuous market access.

A full conversion from subsistence grain production to specialized apple production would reduce the flexibility of type in the farming system. While cash crops are exposed to market uncertainty, revenues from years with high prices may serve as a buffer compensating for occasional crop failure in subsistence production. The most flexible solution is therefore to convert only a small share of the cultivated land to apple production, while maintaining grain production in most of the cultivated land. The combination of subsistence and market production reduces the dependency on each strategy, thereby reducing the vulnerability to climatic and market variability. This kind of combined farming practice is currently the common strategy among the farmers of Jharkot. No household have so far chosen to specialize fully in producing apples for the market.

Another flexibility of type lies in the utilization of wild plants in the common lands. Non-timber forest products (NTFP) are a collection of wild growing edible plants, medicinal plants, and non-edible plant resources traditionally used in subsistence based farming systems and some which are objects of trade. In Mustang at least 70 species are used for medicine by amchis, Tibetan doctors [26], while more than one hundred NTFP species are consumed by the local people of Mustang [36]. The collection, use and sale of NTFP is widespread also in other districts such as Manang [37]. In Jharkot, NTFPs contribute to increase the opportunity space of productive activities and offer occupational alternatives in lean seasons. Several community projects based on NTFP have been 
initiated, though people are still in an early phase of developing niche products for sale in Kathmandu. The local awareness of various potentials for niche product development and the existing capacity for local cooperation serves Jharkot community with flexibility of type.

Among the economically most important species is yarzagumba (Cordyceps sinensis). Yarzagumba is a larva infected by a parasite fungus, and the name literally means "winter worm-summer grass" [38]. In traditional Tibetan medicine it is eaten dry or soaked in liquor to relieve fatigue, altitude sickness, and knee pain, while various additional medical properties are documented [38,39]. Yarzagumba can be found in alpine meadows at 4000 m.a.s.l. from late May when the parasite fungus is properly developed. In early summer, young men from Jharkot go camping for several weeks and search for yarzagumba. The gathering is individual but the harvest is sold to contractors, who in turn export the pieces to China and Singapore. As an indicator of the substantial potential value in this business, people in Manang district sold yarzagumba worth 15 million NPR in 2005 [40]. Gathering is only allowed for a certain period of time in a dedicated area and it is regulated at the VDC level, which is the lowest administrative unit in Nepal. The annual yarzagumba gathering represents one of the existing opportunities of type in the farming system to utilize the rich diversity of non-timber forest products found in the alpine meadows. The benefit of economic diversification by making use of non-timber forest products have also been demonstrated in other mountain farming systems [41].

\section{Temporal Flexibility}

In a short-term perspective, temporal flexibility here refers to the ability to rapidly rearrange the factors of production in order to make the most out of scarce resources. Irrigation water is seasonally a constraint to agricultural production in Jharkot, but at the same time water is a resource with high short-term temporal flexibility. Through the irrigation system, water can rapidly be reallocated from apple orchards to grain or vegetable fields. In comparison, to plant new trees takes several years from the decision is made to the results are seen. While the conversion of a grain field to an apple orchard reduces short-term flexibility for that particular field, diversification increases the temporal flexibility at the household farm system level by enabling farmers to rapidly reallocate their scarce resources. Since land availability is currently not constrained in Jharkot, the main concerns of the farmers are how to best allocate their labor and water in the peak seasons. The combination of staple food crops, vegetables, cash crops and non-timber forest products gives the farming system high temporal flexibility and renders possible a deliberate spending of water and labor in times of relative scarcity, which is essential for the utility of opportunities of type and capacity of scope. At the same time, flexibility of type in the cultivated fields, orchards and common lands reduce the sensitivity to seasonal drought since not all crops are in critical need of irrigation at the same time. Only a combination of all three aspects of flexibility can reflect the adaptive capacity of the farming system to short-term climatic variability.

Some farmers in Jharkot reflect on their farming strategy also in a long-term perspective, considering the opportunities for their children to engage in farming in the future. In the context of uncertain local impacts of large-scale changes, the adaptive capacity of Jharkot farming system depends on people's ability not only to rapidly respond to changing conditions of production, but also to strategically plan for future uncertainty. One farmer (male, 48) expressed that: "We have to make 
new things, opportunities here, or else the children will not come home. Hotels, apple trees, that's good. At first I didn't want to plant [the apple trees], I said, 'who will come back here to keep them?' But my wife wanted to, for the children. And it's good."

According to Guillet ([42], p.567) "a potential for change in strategy" is one of the basic elements of adaptation in mountain environments. By making use of the range of crops and productive strategies which are possible to adopt, the farmers of Jharkot explore the existing opportunity situation in the village. If food prices remain as high and volatile in the future as projected by the FAO (2012), local food production might increase its importance in achieving household food security. While seasonal migration represents the system's flexibility of scope in labor, too much migration involves a loss of flexibility as it will be increasingly cumbersome to return to farming as time passes by in the city. In the words of a mother (55): "When the children are home, they don't work in the fields. They can't work in the fields, they don't know, they are students". A father (48) who had recognized this stated that "I always bring my children back home, in every holiday. So they remember, or else they will forget, if they are not here for many years". In one particular case, a household from Jharkot chose to give up its flexibility to return and instead abandoned their house and fields altogether, moving permanently to Kathmandu. As land cannot be sold to non-Jharkot residents, the family chose to permanently hand over their fields to the community, which in turn manages the fields collectively by sharecropping them out and letting the owner's share of the yields be distributed among the village households. This strategy leaves the community in control over the land, while the original owners have lost their flexibility to return. Another household, also of which all members live permanently in Kathmandu, chooses to keep their house and fields empty in Jharkot. One of the sons occasionally visits the home village and although he does not farm or keep livestock, he manages to keep the social relations active. The long-term flexibility to return to farming is to some extent maintained for this household. To utilize the space of maneuver once in a while is necessary in order to preserve flexibility in the system [18].

\section{Flexibility, Adaptive Capacity and Sustainability}

The case from Jharkot shows that flexibility is an essential feature of the adaptive capacity of this small-scale farming system to variable and increasingly uncertain production conditions. The case supports the conclusion of Aase et al. [6] that Himalayan farming communities are better described as dynamic than fragile, and that farming flexibility is a highly viable strategy for adaptation under conditions of uncertainty.

A similar conclusion is reached by Niemeijer based on his analysis of African agriculture. He states that "[ $t$ ]he more dynamic the natural or social environment, the more important it becomes to rapidly adjust subsistence patterns to benefit from new opportunities and to avoid pressing constraints" ([43], p. 93). Niemeijer argues that African agriculture is strongly characterized by flexibility and adaptability, and that it is precisely the dynamic response of African agriculture to changing natural and social environments that have guaranteed its long term survival. Guvele [44] concludes that crop diversification reduces income variability among Sudanean farmers facing uncertainties in production costs, yields, and market prices. In Bangladesh, Rahman [45] found that crop specialization has reduced productivity, while crop diversification has improved farm efficiency 
by allowing for more effective use of household labor in lean seasons and avoiding bottlenecks in labor usage. Rahman concludes that by combining subsistence and cash crop production, farmers are enabled to select enterprises that complement each other, given the high seasonality in labor demand for each crop. The conclusions of these studies are much similar to the case of Jharkot. Instead of generalizing single practices from particular cases, one may rather look for the transferability of some general structural aspects [46]. It seems that in small-scale farming systems, the combination of subsistence and market production is a more flexible strategy than specialization in either one. A diversified farming practice preserves the opportunities of farmers to rapidly adjust the scope of each crop and reallocate scarce productive resources such as labor and water to alternative crops in response to changing conditions, thereby keeping the short-term temporal flexibility high.

Flexibility in response to climatic and other external changes and management of biophysical diversity is thus essential for successful adaptation of agriculture in a dynamic world [4]. In this way, flexibility helps ensuring the general sustainability of small-scale farming systems under dynamic and uncertain production conditions. The sustainability of farming systems here refers to their ability to maintain their function as systems of food production. Since the importance of flexibility for adaptive capacity in agriculture seems to be noted in many parts of the world, some lessons on how flexibility is important might be transferable from one case to another.

Based on the case from Jharkot, we argue that the general flexibility of a small-scale mountain farming system depends on maintaining the potentialities for change in production. Flexibility of scope is not to seek intensification, but rather to keep some buffers of unexploited capacity in the factors of production which can be spent in times of need or for exploration of new opportunities for diversification in crops and productive practices. To maintain a diversified composition of crops and wild plants gives the system flexibility of type by allowing for opportunities for change of crops that may be cultivated or gathered. Diversification, rather than specialization, enables flexibility of type. Local innovation may increase the flexibility of type if the total range of possible crops and productive practices which are available in the farming system is increased. The ability to rapidly respond to changing conditions of production by combining and alternating between different crops and production practices, and rapidly reallocate scarce productive resources to where they are most needed for the time being, constitute the temporal flexibility of a farming system. In this way, flexibility of scope, type and temporality represent the capacity of a farming system to adapt to locally uncertain climatic and market conditions.

However, constrained capacity in one central variable may function as a bottleneck for the general performance of the system. If a central goal is to increase flexibility, it is therefore important to address these bottlenecks and look for ways to either increase the capacity of the constrained system variables, or rearrange the system in order to make agricultural production less vulnerable to occasional scarcity of the constrained variable. Institutional, political, social or religious structures might also play a role in either imposing barriers to flexibility, or contribute to enable farming system flexibility. There are a vast diversity of small-scale farming systems embedded in highly different contexts across the world, which result in a variety of particular opportunities for and constraints to adaptation in each farming system. Adams and Mortimore [21] note that there is no simple relationship between intensification and sustainability, as in some farming systems there may be capacity for intensification without reaching the ecological thresholds of vital system variables, while in other farming systems 
intensification might push the agricultural ecosystem towards production that is not sustainable in the long run. The term "sustainable intensification" implies that there is room for intensification of agricultural production while at the same time maintaining flexibility of scope through buffers of unused capacity in the farming system or alternatively, by permanently relying on external inputs. If, however, the exploited capacity of one important system variable is pushed towards its limit, the system lacks flexibility of scope for that variable and the result may be loss of sustainability. Reduced soil fertility and increasing sensitivity for seasonal water scarcity are examples of such a process. Flexibility thus offers freedom of manoeuver that can be lost in the process of intensification [21]. As long as each case is analyzed in its specific context, to look for uncommitted potentialities for change and the factors that constrain flexibility is one way of approaching adaptive capacity in small-scale farming systems under conditions of uncertainty. The case from Jharkot demonstrates how farming system flexibility may be analyzed by looking for the opportunities for change in terms of flexibility of scope, type and temporality, as the ability to rapidly adjust agricultural production to uncertain local impacts of large-scale processes of change.

\section{Conclusions}

The rising temperatures and changing patterns of precipitation which are expected consequences from global climate change, combined with high and volatile food prices in the international markets, are some of the large-scale changes to which small-scale farmers must adapt. In the diverse Himalayan region, the local impacts of global changes are highly differentiated and uncertain. The adaptive capacity of small-scale farmers largely depends on their flexibility to adapt agricultural production to uncertain conditions of production. Defining flexibility as "uncommitted potentialities for change" ([18], p.497), this paper argues that farming system flexibility may be analyzed in terms of the three aspects flexibility of scope, flexibility of type and temporal flexibility. Available, but currently unexploited capacity of scope in factors of production, serve the purpose of buffers which give opportunities for change in agricultural production. A diversified crop composition and the combination of a variety of productive strategies reduce farmers' vulnerability to climatic or market variability and enable farmers to alternate between different productive strategies. The ability to rapidly shift production capacity of land, labor, water or capital to where it is most needed for the time being constitutes the capacity to adapt to unpredictable changes.

For mountain communities, greater integration in regional and global markets may amplify local vulnerabilities through higher dependency on food and labor markets. However, greater market integration may also create new opportunities in agriculture for market production of vegetables, fruits, herbs and medicinal plants. Successful diversification into high-value crops have increased incomes and improved food security in many mountain communities $[47,48]$. The case of Jharkot shows how diversified practices can enable farming flexibility under uncertain production conditions by increasing the local opportunity situation of possible crops and production strategies.

If high and volatile food prices or limited labor opportunities for migrant workers reduce the ability to secure an income from off-farm work, people in Jharkot might again wish to invest a larger share of their labor in agricultural production. If they choose to do so, there are several opportunities for change in the farming system that they might explore. They can reclaim abandoned fields such as in 
Manang [6] and raise larger herds of livestock; they can plant apple trees and vegetables as cash crops, and invest more in collecting medicinal plants and develop other non-timber forest products. Although all households are probably not willing or capable to explore every potentiality for change in production, opportunities at the village level constitute the flexibility of type in the farming system of Jharkot. Through the recent initiatives to develop local niche products, the community of Jharkot has proven the ability to manage collective projects in combination with private entrepreneurship. Innovative creation of local business opportunities may expand the flexibility of type in the system. In a long-term perspective, the creation of agriculture related business opportunities may even inspire the younger generation to engage more in farming.

However, relative shortage of one factor of production may constrain the performance of the whole farming system and impose bottlenecks to agricultural production. Too little irrigation meltwater in the spring is one such bottleneck in Jharkot; a problem which could become even more severe if the snowcover is reduced following rising temperatures. The community of Jharkot has recently addressed this problem. Through establishing a community project they have constructed an additional irrigation canal from a well located several kilometers away from the village; a water source which until now has been underutilized because of the difficult topography in the area. Now, the community has found it worth the investment to explore this uncommitted opportunity. Capital has been raised from external sources and the construction work was done by representatives from all households in the village. The people of Jharkot's capacity for local cooperation and active local institutions for management and maintenance of common property are essential for completion of such a project.

However, if global climate change in the future results in such drastic temperature increases as are now projected for Himalaya, the impacts on local water supply may be too comprehensive to be solved by local adaptation measures such as constructing more and longer irrigation canals. But still, as long as the water availability is not radically altered in Jharkot, there are vast opportunities for maintained and even increased agricultural production in this farming system in the years to come. The combination of various forms of production for subsistence and for the market reduces the dependency on each strategy. The risk of large economic losses due to unpredictable events such as seasonal drought, crop failure and pest attacks, but also market uncertainty due to volatile prices or periodical road blocks, is reduced through diversification of crops and productive strategies.

An analysis of flexibility must address both the opportunities for, and constraints to, change in each specific case and pay attention to both the upper and the lower tolerance limits of vital farming system variables. The analytical approach to study farming flexibility in terms of flexibility of scope, type and temporality might be relevant for studies of adaptive capacity to climatic and market uncertainty of small-scale farming systems in other parts of the world.

Although the perception of the Himalayan environment as vulnerable and fragile is remarkably persistent [49-51], others prefer to characterize the Himalayan region as highly dynamic [5,6,52]. A dynamic environment calls for flexible responses. For Himalayan farming systems facing a climatically uncertain future, ability to change rapidly is of vital importance for successful adaptation. Returning to the general argument of Gregory Bateson [18], to create flexibility is to create preadaptation to unpredictable change. 


\section{Acknowledgments}

This article draws on a Master Thesis by N. Holmelin, approved 9 June 2010 by the Department of Geography, University of Bergen, Norway. Further work on this article has been done as part of Himalayan Climate Change Adaptation Programme (HICAP), a research programme coordinated by Center for International Climate and Environmental Research-Oslo (CICERO), International Centre for Integrated Mountain Development (ICIMOD) in Kathmandu and United Nations Environment Programme (UNEP) GRID-Arendal. HICAP is funded by the Norwegian Ministry of Foreign Affairs. Preliminary versions of the article have been presented at Climate Adaptation Futures 2012: International Conference on Climate Adaptation, 29-31 May 2012, University of Arizona, USA, at the NFU Conference: Development for a Finite Planet, 26-27 November 2012, Oslo, Norway and at Exploring Sustainability: Norwegian Geographers' Association Conference, 21-22 January 2011, Losby, Norway. We wish to thank the Faculty of Social Sciences at the University of Bergen for financial support for fieldwork, Keshav Prasad Paudel at the Department of Geography, University of Bergen for assistance when preparing the map, and lastly we thank two anonymous referees for their helpful comments and suggestions.

\section{Conflict of Interest}

The authors declare no conflict of interest.

\section{References}

1. Nakashima, D.J.; Galloway McLean, K.; Thulstrup, H.D.; Ramos Castillo, A.; Rubis, J.T. Weathering Uncertainty. Traditional Knowledge for Climate Change Assessment and Adaptation; UNESCO and United Nations University: Paris and Darwin, France and, Australia, 2012.

2. MacDonald, K.I. Rationality, representation, and the risk mediating characteristics of a Karakoram mountain farming system. Hum. Ecol. 1998, 26, 287-321.

3. Bishop, N.H. Himalayan herders; Harcourt Brace \& Company: Orlando, Florida, USA, 1998.

4. Brookfield, H. Intensification, and alternative approaches to agricultural change. Asia Pac. Viewpoint 2001, 42, 181-192.

5. Mishra, C.; Prins, H.H.T.; Wieren, S.E.V. Diversity, risk mediation, and change in a TransHimalayan agropastoral system. Hum. Ecol. 2003, 31, 595-609.

6. Aase, T.H.; Chaudhary, R.P.; Vetaas, O.R. Farming flexibility and food security under climatic uncertainty: Manang, Nepal Himalaya. Area 2010, 42, 228-238.

7. Cruz, R.V.; Harasawa, H.; Lal, M.; Wu, S.; Anokhin, Y.; Punsalmaa, B.; Honda, Y.; Jafari, M.; Li, C.; Ninh, N.H. Asia. Climate Change 2007: Impacts, Adaptation and Vulnerability. Contribution of Working Group II to the fourth Assessment Report of the Intergovernmental Panel on Climate Change; ISBN:978-0521-88010-7; Cambridge University Press: Cambridge, UK, 2007.

8. Kehrwald, N.M.; Thompson, L.G.; Tandong, Y.; Mosley-Thompson, E.; Schotterer, U.; Alfimov, V.; Beer, J.; Eikenberg, J.; Davis, M.E. Mass loss on Himalayan glacier endangers water resources. Geophys. Res. Lett. 2008, 35, 1-6. 
9. Barnett, T.P.; Adam, J.C.; Lettenmaier, D.P. Potential impacts of a warming climate on water availability in snow-dominated regions. Nature 2005, 438, 303-309.

10. Shrestha, A.B.; Wake, C.P.; Mayewski, P.A.; Dibb, J.E. Maximum temperature trends in the Himalaya and its vicinity: An analysis based on temperature records from Nepal for the period 1971 - 94. J. Clim. 1999, 12, 2775-2786.

11. Salick, J.; Byg, A. Indigenous Peoples and Climate Change; Tyndall Centre for Climate Change Research: Oxford, UK, 2007.

12. Xu, J.; Grumbine, R.E.; Shresta, A.; Eriksson, M.; Yang, X.; Wang, Y.; Wilkes, A. The melting Himalayas: Cascading effects of climate change on water, biodiversity and livelihoods. Conserv. Biol. 2009, 23, 520-530.

13. Price, M.F. Climate change in mountain regions: A marginal issue? The Environmentalist 1995, 15, 272-280.

14. Morton, J.F. The impact of climate change on smallholder and subsistence agriculture. PNAS 2007, 104, 19680-19685.

15. Battisti, D.S.; Naylor, R.L. Historical warnings of future food insecurity with unprecedented seasonal heat. Science 2009, 323, 240-244.

16. FAO. The State of Food Insecurity in the World. How does International Price Volatility Affect Domestic Economies and Food Security? Food and Agricultural Organization of the United Nations: Rome, Italy, 2011; ISBN 978-92-5-106927-1.

17. David, C.; Mundler, P.; Demarle, O.; Ingrand, S. Long-term strategies and flexibility of organic farmers in southeastern France. Int. J. Agr. Sust. 2010, 8, 305-318.

18. Bateson, G. Steps to an Ecology of Mind; University of Chicago Press: Chicago, IL, USA, 1972.

19. Mascarenhas, M. Farming system research: Flexible diversification of a small family farm in southeast Michigan. Agr. Hum. Values 2001, 18, 391-401.

20. Weiss, C.R. On flexibility. J. Econ. Behav. Organ. 2001, 46, 347-356.

21. Adams, W.M.; Mortimore, M.J. Agricultural intensification and flexibility in the Nigerian Sahel. Geogr. J. 1997, 163, 150-160.

22. Carlsson, B. Flexibility and the theory of the firm. Int. J. Ind. Organ. 1989, 7, 179-203.

23. Lev, L.; Campbell, D.J. The temporal dimension in farming systems research: The importance of maintaining flexibility under conditions of uncertainty. J. Rur. Stud. 1987, 3, 123-132.

24. Dixon, J.; Gulliver, A. Farming Systems and Poverty. Improving Farmers' Livelihoods in a Changing World; FAO and World Bank: Rome and Washington DC, Italy and USA, 2001.

25. Turner, B.L.; Brush, S.B. Comparative Farming Systems; The Guildford Press: New York, NY, USA, 1987.

26. NTNC. Sustainable Development Plan of Mustang; National Trust for Nature Conservation (NTNC)/Government of Nepal/United Nations Environmental Program (UNEP): Kathmandu, Nepal, 2008.

27. Fort, M. Geomorphic and hazards mapping in the dry, continental Himalaya: 1:50,000 maps of Mustang district, Nepal. Mt. Res. Dev. 1987, 7, 222-238.

28. FAO. Food Insecurity and Vulnerability in Nepal: Profiles of Seven Vulnerable Groups; Agricultural and Development Economics Division, The Food and Agricultural Organization of the United Nations (FAO): Rome, Italy, 2004. 
29. Von Führer-Haimendorf, C. Himalayan Traders; St. Martin's Press: New York, New York, USA, 1975.

30. Jackson, D.P. Notes on the history of Se-Rib, and nearby places in the Upper Kali Gandaki valley. Kailash: J. Himalayan Stud. 1978, 6, 195-228.

31. Vinding, M. The Thakali. A Himalayan Ethnography; Serindia Publications: London, UK, 1998.

32. Aase, T.H.; Chapagain, P.S. Nepali agriculture in crisis? Stud. Nepali Hist. Soc. 2005, 10, 39-56.

33. Andersen, P.; Chapagain, P.S. Changing diet and nutrient uptake in Manang. In Local effects of global changes in the Himalayas: Manang, Nepal; Chaudhary, R.P., Aase, T.H., Vetaas, O.R., Subedi, B.P., Eds.; Tribhuvan University and University of Bergen: Kathmandu and Bergen, Nepal and Norway, 2007.

34. Aase, T.H. Local Responses to Large Scale Global Changes in the Himalayas. In BASAS Annual Conference 2007; British Association for South Asian Studies: Cambridge, UK, 2007.

35. Veblen, T. The Theory of the Leisure Class: An Economic Study of Institutions; Aakar Books: Delhi, India, 2005.

36. Chhetri, H.B.; Gupta, V.N.P. A survey of non-timber forest products (NTFP) in Upper Mustang. Sci. World 2007, 5, 89-94.

37. Bhattarai, S.; Chaudhary, R.P.; Taylor, R.S.L. Prioritization and Trade of Ethnomedicinal Plants by the People of Manang District, Central Nepal. In Local Effects of Global Changes in the Himalayas: Manang, Nepal; Chaudhary, R.P., Aase, T.H., Vetaas, O.R., Subedi, B.P., Eds.; Tribhuvan University and University of Bergen: Kathmandu and Bergen, Nepal and Norway, 2007.

38. Hsu, T.-H.; Shiao, L.-H.; Hsieh, C.; Chang, D.-M. A comparison of the chemical composition and bioactive ingredients of the Chinese medicinal mushroom Dongchongxiacao, its counterfeit and mimic, and fermented mycelium of Cordyceps Sinensis. Food Chem. 2002, 78, 463-469.

39. Nishizawa, K.; Torii, K.; Kawasaki, A.; Katada, M.; Ito, M.; Terashita, K.; Aiso, S.; Matsuoka, M. Antidepressant-like effect of Cordyceps Sinensis in the mouse tail suspension test. Biol. Pharm. Bull. 2007, 30, 1758-1762.

40. Chaudhary, R.P.; Aase, T.H.; Vetaas, O.R. Globalisation and People's Livelihood: Assessment and Prediction for Manang, Trans-Himalayas, Nepal. In Local Effects of Global Changes in the Himalayas: Manang, Nepal; Chaudhary, R.P., Aase, T.H., Vetaas, O.R., Subedi, B.P., Eds.; Tribhuvan University and University of Bergen: Kathmandu and Bergen, Nepal and Norway, 2007.

41. Partap, T. Sustainable land management in marginal mountain areas of the Himalayan region. Mt. Res. Dev. 1999, 19, 251-260.

42. Guillet, D. Toward a cultural ecology of mountains: The central Andes and the Himalayas compared. Curr. Anthropol. 1983, 24, 561-567.

43. Niemeijer, D. The dynamics of African agricultural history: Is it time for a new development paradigm? Dev. Change 1996, 27, 87-110.

44. Guvele, C.A. Gains from crop diversification in the Sudan Gezira scheme. Agr. Syst. 2001, 70, 319-333.

45. Rahman, S. Whether crop diversification is a desired strategy for agricultural growth in Bangladesh? Food Policy 2009, 34, 340-349. 
46. Gobo, G. Sampling, Representativeness and Generalizability. In Qualitative Research Practice; Seale, C., Gobo, G., Gubrium, J.F., Silverman, D., Eds.; SAGE: London, UK, 2004.

47. Jodha, N.S. Adaptation strategies against growing environmental and social vulnerabilities in mountain areas. Himalayan J. Sci. 2005, 3, 33-42.

48. Choudhary, D.; Pandit, B.H.; Kinhal, G.; Kollmair, M. Pro-Poor Value Chain Development for High Value Products in Mountain Regions: Indian Bay Leaf; ICIMOD: Kathmandu, Nepal, 2011.

49. Guthman, J. Representing crisis: The theory of Himalayan environmental degradation and the project of development in post-Rana Nepal. Dev. Change 1997, 28, 45-69.

50. Rai, S.C.; Gurung, A. Raising awareness of the impacts of climate change: Initial steps in shaping policy in Nepal. Mt. Res. Dev. 2005, 25, 316-320.

51. Ives, J.D. Himalayan Perceptions: Environmental Change and the Well-Being of Mountain Peoples, 2nd ed.; Routledge: London, UK, 2006.

52. Subedi, B.P. Migration and Tourism in the Trans-Himalayan Region: Studies on Changing Livelihood Patterns of Upper Manang Community in Nepal. In Local Effects of Global Changes in the Himalayas: Manang, Nepal; Chaudhary, R.P., Aase, T.H., Vetaas, O.R., Subedi, B.P., Eds.; Tribhuvan University and University of Bergen: Kathmandu and Bergen, Nepal and Norway, 2007.

(C) 2013 by the authors; licensee MDPI, Basel, Switzerland. This article is an open access article distributed under the terms and conditions of the Creative Commons Attribution license (http://creativecommons.org/licenses/by/3.0/). 